IFAS Extension

\title{
Fumigant Nematicides Registered for Vegetable Crop Use in Florida ${ }^{1}$
}

\section{J. W. Noling ${ }^{2}$}

Table 1. List of multispectrum fumigant nematicides currently registered for use on different Florida crops.

\begin{tabular}{|c|c|c|c|c|c|}
\hline Crop / Use & $\begin{array}{l}\text { Methyl Bromide } \\
\text { Chloropicrin50:50 }\end{array}$ & $\begin{array}{l}\text { Telone II } \\
\text { Telone EC } \\
\text { Telone C17 orTelone C35 } \\
\text { Telone Inline }\end{array}$ & $\begin{array}{l}\text { Dimethyl } \\
\text { Disulfide(DMDS) }\end{array}$ & $\begin{array}{l}\text { Pic Clor } 60 \\
\text { Pic Clor } 60 \text { EC }\end{array}$ & $\begin{array}{l}\text { Metam Sodium } \\
\text { Metam Potassium }\end{array}$ \\
\hline Asparagus & $\mathbf{x}$ & $\mathbf{X}$ & & $\mathbf{x}$ & $\mathbf{x}$ \\
\hline Broccoli & $x$ & $\mathbf{x}$ & & $\mathbf{x}$ & $\mathbf{x}$ \\
\hline Cabbage & $x$ & $\mathbf{x}$ & & $x$ & $x$ \\
\hline Cantaloupe & $x$ & $x$ & & $x$ & $x$ \\
\hline Cauliflower & $\mathbf{x}$ & $\mathbf{x}$ & & $x$ & $\mathbf{x}$ \\
\hline Corn & $x$ & $x$ & & $x$ & $x$ \\
\hline Cucumber & $x$ & $\mathbf{x}$ & & $\mathbf{x}$ & $\mathbf{x}$ \\
\hline Eggplant & $x$ & $x$ & $x$ & $x$ & $\mathbf{x}$ \\
\hline Melon & $\mathbf{x}$ & $x$ & $\mathbf{x}$ & $x$ & $x$ \\
\hline Onions & $x$ & $\mathbf{x}$ & & $\mathbf{x}$ & $\mathbf{x}$ \\
\hline Peppers & $x$ & $x$ & $\mathbf{x}$ & $x$ & $x$ \\
\hline Tomato & $x$ & $x$ & $x$ & $x$ & $x$ \\
\hline Sweet corn & $\mathbf{x}$ & $\mathbf{x}$ & & $\mathbf{x}$ & $\mathbf{x}$ \\
\hline Sweet potato & $\mathbf{x}$ & $x$ & & $x$ & $x$ \\
\hline Squash & $x$ & $x$ & $x$ & $x$ & $x$ \\
\hline Strawberry & $\mathbf{x}$ & $\mathbf{x}$ & $\mathbf{x}$ & $x$ & $\mathbf{x}$ \\
\hline Vegetable & $\mathbf{x}$ & $x$ & & $x$ & \\
\hline Plant bed & $x$ & & & & \\
\hline Seed bed & $\mathbf{x}$ & & & & \\
\hline $\begin{array}{l}\text { Crop land } \\
\text { (all crops) }\end{array}$ & & $x$ & & $x$ & \\
\hline Fruit nut vine & $x$ & $\mathbf{x}$ & & $\mathrm{X}$ & \\
\hline Field crops & & $\mathbf{x}$ & & $\mathbf{x}$ & \\
\hline
\end{tabular}

1. This document is ENY-064, one of a series of the Entomology and Nematology Department, Florida Cooperative Extension Service, Institute of Food and Agricultural Sciences, University of Florida. Original publication date January 2013. Visit the EDIS website at http://edis.ifas.ufl.edu.

2. J.W. Noling, professor, Entomology and Nematology Department, Citrus Research and Education Center in Lake Alfred, Florida, Cooperative Extension Service, Institute of Food and Agricultural Sciences, University of Florida, Gainesville, FL 32611. 


\begin{tabular}{|l|l|l|l|l|}
\hline Nursery crops & $\mathbf{X}$ & $\mathbf{X}$ & $\mathbf{X}$ & $\mathbf{X}$ \\
\hline Food crops & $\mathbf{X}$ & & $\mathbf{X}$ \\
\hline Fiber crops & & & $\mathbf{X}$ \\
\hline Ornamentals & & & \\
\hline Turf & & & \\
\hline Floral crops & $\mathbf{X}$ & & \\
\hline $\begin{array}{l}\text { Non-food } \\
\text { crops }\end{array}$ & $\mathbf{X}$ & & \\
\hline $\begin{array}{l}\text { Non-feed } \\
\text { crops }\end{array}$ & $\mathbf{X}$ & & & \\
\hline
\end{tabular}

This information was compiled as a quick reference for the commercial Florida vegetable grower. The mentioning of a chemical or proprietary product in this publication does not constitute a written recommendation or an endorsement for its use by the University of Florida, Institute of Food and Agricultural Sciences, and does not imply its approval to the exclusion of other products or practices that may be suitable. Products mentioned in this publication are subject to changing state and federal rules, regulations, and restrictions. Additional products may become available or approved for use. Growers have the final responsibility to guarantee that each product is used in a manner consistent with its label. All soil fumigation products containing methyl bromide are being reduced in supply and availability, with an expected complete phase-out for soil fumigation use in 2015.

Table 2. List of multispectrum fumigant nematicides currently registered for use in Florida including maximum rates and specific details for field application.

\begin{tabular}{|c|c|c|c|}
\hline \multirow[t]{2}{*}{ Nematicide } & \multicolumn{2}{|c|}{ Broadcast Application ${ }^{1}$} & \multirow[t]{2}{*}{ In the Row Applications } \\
\hline & $\begin{array}{l}\text { Gallons or Lbs } \\
\text { Per acre }\end{array}$ & $\begin{array}{l}\text { FI oz / } 1000 \text { ft / chisel } \\
\text { spaced 12" apart }\end{array}$ & \\
\hline $\begin{array}{l}\text { Methyl Bromide } \\
\text { Chloropicrin }\end{array}$ & \multicolumn{3}{|c|}{$\begin{array}{l}\text { A critical use exemption (CUE) for continuing use of methyl bromide for tomato, pepper, and eggplant has } \\
\text { been awarded for calendar year } 2013 \text {. Specific certified uses and labeling requirements for CUE acquired } \\
\text { methyl bromide must be satisfied prior to grower purchase and use in these crops. Quantity and formulation } \\
\text { availability are subject to change. }\end{array}$} \\
\hline Telone $\|^{2,3}$ & 9 to $12 \mathrm{gal}$ & 26 to 35 & $\begin{array}{l}\text { For any row spacing, application rates given may be } \\
\text { concentrated in the row, but shall never exceed the labeled } \\
\text { maximum for broadcast applications. Consult the product label } \\
\text { for additional detail. }\end{array}$ \\
\hline Telone $\mathrm{EC}^{2,3}$ & 9 to $12 \mathrm{gal}$ & 26 to 35 & $\begin{array}{l}\text { For any row spacing, application rates given may be } \\
\text { concentrated in the row, but shall never exceed the labeled } \\
\text { maximum for broadcast applications. Consult the product label } \\
\text { for additional detail and chemigation equipment requirement. }\end{array}$ \\
\hline Telone C-172,3 & 10.8 to $17.1 \mathrm{gal}$ & 31.8 to 50.2 & $\begin{array}{l}\text { For any row spacing, application rates given may be } \\
\text { concentrated in the row, but shall never exceed the labeled } \\
\text { maximum for broadcast applications. Consult the product label } \\
\text { for additional detail. }\end{array}$ \\
\hline Telone C-35 2,3 & 13 to $20.5 \mathrm{gal}$ & 38 to 60 & $\begin{array}{l}\text { For any row spacing, application rates given may be } \\
\text { concentrated in the row, but shall never exceed labeled } \\
\text { maximum for broadcast applications. Consult the product label } \\
\text { for additional detail. }\end{array}$ \\
\hline $\begin{array}{l}\text { Telone } \\
\text { InLine } 2,3\end{array}$ & 13 to $20.5 \mathrm{gal}$ & - & $\begin{array}{l}\text { For drip fumigation, consult the product label for overall rate, } \\
\text { drip concentration and flow modifying application directions. }\end{array}$ \\
\hline Pic Clor $60^{2,3}$ & $19.5-31.5 \mathrm{gal}$ & 57 to 90 & $\begin{array}{l}\text { Consult product label for overall rate and chisel flow modifying } \\
\text { application directions. }\end{array}$ \\
\hline $\begin{array}{l}\text { Pic Clor } \\
60 \mathrm{EC}^{2,3}\end{array}$ & $19.5-31.5 \mathrm{gal}$ & - & $\begin{array}{l}\text { For drip fumigation, consult product label for proportionately } \\
\text { reduced overall rates, drip concentration and drip flow } \\
\text { modifying directions and procedures. }\end{array}$ \\
\hline Vapam HL & $75 \mathrm{gal}$ & - & $\begin{array}{l}\text { For drip or in-row fumigation and crop termination, consult } \\
\text { product label for proportionately reduced overall rates, drip } \\
\text { concentration and flow modifying directions and procedures. }\end{array}$ \\
\hline
\end{tabular}




\begin{tabular}{|c|c|c|c|}
\hline KPam HL & $60 \mathrm{gal}$ & - & $\begin{array}{l}\text { For drip or in-row fumigation and crop termination, consult } \\
\text { product label for proportionately reduced overall rates, drip } \\
\text { concentration and flow modifying directions. }\end{array}$ \\
\hline $\begin{array}{l}\text { Dimethyl }{ }^{2} \\
\text { Disulfide (DMDS) }\end{array}$ & $51.3 \mathrm{gal}$ & - & $\begin{array}{l}\text { Compared to broadcast application, apply proportionately less } \\
\text { for in the row applications based on the ratio of bed width to } \\
\text { row spacing. Consult the product label for additional detail and } \\
\text { rate modifying recommendation. }\end{array}$ \\
\hline \multicolumn{4}{|c|}{$\begin{array}{l}\text { 'Gallons / acre and fluid ounces / } 1000 \text { feet provided only for mineral soils. Higher rates may be possible for heavier textured soils (loam, silt, } \\
\text { clay) or highly organic soils. } \\
\text { 'All of the fumigants mentioned are for retail sale and use only by state-certified applicators or persons under their direct supervision. New } \\
\text { supplemental labeling for the Telone products must be in the hands of the user at the time of application. See label details for additional use } \\
\text { restrictions based on soil characteristics, buffer zones, requirements for Personal Protective Equipment (PPE), mandatory good agricultural } \\
\text { practices (GAPs), product and applicator training certification, and rate modifying recommendations with use of highly retentive mulch films. } \\
{ }^{3} \text { Higher application rates are possible in the presence of cyst-forming nematodes. }\end{array}$} \\
\hline \multicolumn{4}{|c|}{$\begin{array}{l}\text { Rates are believed to be correct for products named and similar products of other brand names when applied to mineral soils. Higher rates are } \\
\text { required for muck (organic) soils. However, the grower has the final responsibility to see that each product is used legally; read the label of } \\
\text { the product to be sure that you are using it properly. }\end{array}$} \\
\hline
\end{tabular}

Many different soil fumigants have been evaluated in Florida field trials to characterize pest control efficacy and crop yield response (Table 3 ). The results of these research trials have provided basis for overall generalization of pesticidal activity for each of the different fumigant chemicals. As a standard for comparison, this research has repeatedly demonstrated methyl bromide to be very effective against a wide range of soilborne pests, including nematodes, diseases, and weeds. Chloropicrin has proved very effective against diseases but is seldom effective against nematodes or weeds. Telone (1,3-dichloropropene) is an excellent nematicide but generally performs poorly against weeds and diseases. Bacterial pathogens have not been satisfactorily controlled by any of the fumigants. Metam sodium and metam potassium can provide good control of weeds when placed properly in the bed; however, research to evaluate modification of rate, placement, and improved application technology has not resolved all problems of inconsistent pest control. Dimethyl disulfide (DMDS), the newest entry to registered fumigants in Florida, has demonstrated good to excellent control of nematodes, disease, and weeds when coapplied with chloropicrin.

Table 3. Generalized summary of maximum use rate and relative effectiveness of various soil fumigants for nematode, soilborne disease, and weed control in Florida.

\begin{tabular}{|c|c|c|c|c|}
\hline \multirow[t]{2}{*}{ FUMIGANT CHEMICAL ${ }^{1}$} & \multirow{2}{*}{$\begin{array}{l}\text { Maximum } \\
\text { UseRate / A }\end{array}$} & \multicolumn{3}{|c|}{ Relative Pesticidal Activity } \\
\hline & & Nematode & Disease & Weed \\
\hline 1) Methyl bromide $50 / 50$ & $350 \mathrm{lb}$ & Good to Excellent & Excellent & Fair to Excellent \\
\hline 2) Chloropicrin ${ }^{2}$ & $300 \mathrm{lb}$ & None to Poor & Excellent & Poor \\
\hline 3) Metam Sodium & $75 \mathrm{gal}$ & Good to Poor & Good to Poor & Good to Poor \\
\hline 4) Telone II & $18 \mathrm{gal}$ & Good to Excellent & None to Poor & Poor \\
\hline 5) Telone C17 & $26 \mathrm{gal}$ & Good to Excellent & Good & Poor \\
\hline 6) Telone C35 & $35 \mathrm{gal}$ & Good to Excellent & Good to Excellent & Poor to Fair \\
\hline 7) Pic-Clor 60 & $300 \mathrm{lb}$ & Good to Excellent & Good to Excellent & Poor to Fair \\
\hline 8) Metam Potassium & $60 \mathrm{gal}$ & Good to Poor & Good to Poor & Good to Poor \\
\hline 9) Dimethyl Disulfide² & $53 \mathrm{gal}$ & Good to Excellent & Good to Excellent & Poor to Excellent \\
\hline \multicolumn{5}{|c|}{$\begin{array}{l}{ }^{1} \text { With new product labels, certified applicators must now consider label changes to maximum application rate, new fumigant training } \\
\text { certifications, personal protective equipment, buffer zone, mandatory good application practices, and other new restrictions and } \\
\text { requirements. } \\
\left.{ }^{2} \text { Broad spectrum pest control achieved when coapplied with chloropicrin ( } 21 \% \mathrm{wt} / \mathrm{wt}\right) \text {. Provides excellent control of nutsedge but poor to fair } \\
\text { control of annual grasses and requires the use of a herbicide for adequate control. }\end{array}$} \\
\hline
\end{tabular}

